\title{
Recent trends in South African water historiography
}

\author{
JOHANN TEMPELHOFF*
}

\begin{abstract}
The discipline of water history is relatively young but since the 1990 s there has been growing interest in the field. In this article an exposition is provided on the origins of the discipline of water history as a subdivision of environmental history. The discussion then turns to an outline of recent developments in the historiography of water history in South Africa. Attention is also given to the possibility of extending the study of this discipline into a number of allied fields.
\end{abstract}

Keywords: historiography, water history, environmental history, technology history, South Africa, outcomes based education (OBE), transdisciplinarity and methodology.

Disciplines and sub-disciplines: Historical studies, historiography, environmental history, water history.

\section{Introduction}

Internationally there has been considerable interest in water history in recent years. This is the outcome of an impressive array of intergovernmental global water initiatives that have been launched since the end of World War II (1939-1945), culminating by the 1990s in major water projects, such as those of the World Water Council

\footnotetext{
Johann Tempelhoff is professor of History in the School of Basic Sciences, NorthWest University, Vaal Triangle Campus. Gauteng, South Africa. Email: johann.tempelhoff@nwu.ac.za. This article is based on a paper presented at the International Conference on Exploring transdisciplinary discourses: water society and the environment in Africa, 20-24 April 2008, at The Nest, Drakensberg, South Africa. The author is grateful to Heather Hoag who facilitated the process of preparing the text. Her comments and constructive proposals are appreciated.
} 
(WWC) and Global Water Partnership (GWP). ${ }^{1}$ Historians, as was the case with most other specialists in science and technology, were attracted to the field by widespread concern in the public realm about issues such as global and national water scarcity; population growth; food security; climate change; and the impact of the deteriorating quality of water.

Although there have always been historians and hydrologists working in the field, their role has traditionally been perceived as providing a historical account of the major accomplishments in engineering, environmental management, governance and development in the realm of water studies. The academic interest in water history in more recent times, at least in developing countries of the world, has emanated in part as a response to trends in globalisation. There is a growing need for more information on indigenous cultures and how historical knowledge can inform governance and management studies. Historians, as is the case with anthropologists and archaeologists, are at least able to provide background information on past developments in an era when the rapid development of communication technologies in all parts of the world have superficially obscured the intrinsic value and tangible traces of natural waterscapes and human culture in former times. ${ }^{2}$ The development of environmental history and its potential role in the modern field of environmental studies, clearly contributed to securing for history a place in what has been an important and growing trend towards interdisciplinarity, multi-disciplinarity and transdisciplinarity in scientific research.

As a discipline history clearly has a role to play in exploring what has on occasion been described as the most researched fluid of all time'. ${ }^{3}$ For some specialists in water studies, such as the hydrologist and geographer Newson, history's value is situated in its ability to shed more light on water

distribution, in both space and time, which is the essential interest to human society and the source of the stimulus to drain, dam, irrigate, or go to war. ${ }^{4}$

1 Global Water Partnership, "Small planet. Big job. Our mission" at http:// www.gwpforum. org/servlet/PSP?chStartupName=_about (accessed on 2008.03.26).

2 In the field of climate change, see UNEP, Africa: atlas of our changing environment, (United Nations Environmental Programme, Division of Early Warning and Assessment, Nairobi, 2008).

3 I Amato, "A new blueprint for water's architecture" in Science, New Series, 245(5065), 1992.06.06, p. 1764.

4 M Newson, Hydrology and the river environment, ([1994], Clarendon Press, Oxford, 2002), p. 9. 
Historians know that water history has a great deal more to offer. It can, for example, make us familiar with technologies of former times that may, in an era of human-induced climate change and resource depletion, be of value in the field of technology and innovation studies. ${ }^{5}$ Historical knowledge can inform us on how to ensure that the quality of public drinking water does not pose a health threat. ${ }^{6}$ History can also, when future water storage facilities are planned, inform decision making on issues of culture and past development, when communities need to be relocated to create space for water storage facilities. ${ }^{7}$ Of particular relevance in present-day Africa is knowledge of the historical appropriation of land and water, the past struggles over these resources, and the best way in which to meet reasonable demands for restitution rights in an era of change management and governance in Africa. ${ }^{8}$

Given the potential of participatory opportunities for historians in the field of water studies, a working definition of water history is necessary. For the purposes of this discussion it is posited that: Water history is the study of human culture and its interaction with the environment, specifically in the spatial context of the hydrosphere, atmosphere and biosphere, in an effort to locate evidence of change that can be interpreted and analysed from observations of past, present and anticipated future trends. Its reliance on information and knowledge generated in other fields of science and technology implies that sustainable water history also has a significant contribution to make in multidisciplinary collaboration.

5 Compare for example, indications of an exponential growth in our knowledge of the early water supply of Bloemfontein between 1960 and 1998. See MCE Van Schoor and JJ Oberholster, "Die fontein van Bloemfontein - voorstelle vir ' $\mathrm{n}$ monument" in Historia, 5(3), September 1960, pp. 169-178; SM Botes, "Die stoommeule en bierbrouery op die terrein van Fort Drury, Bloemfontein, 18681920 " in Suid-Afrikaanse Tydskrif vir Kultuurgeskiedenis, 15(2), November 2001, pp. $1-20$.

6 See W Troesken, The great lead pipe disaster, (MIT Press, Cambridge, Massachusetts, 2006), pp. 13-14, 257; A Fenwick, "Waterborne infectious diseases - could they be consigned to history?" in Science, 313(5790), 2006.08.25, p. 1078; N Planck, "Leafy green sewage" in The New York Times, 2006.09.21 at h t t p : / / w w w. nytimes.com / $2006 / 09 / 21 /$ o pinion / 21 planck.html?ex $=1159070400 \& \mathrm{en}=4531 \mathrm{a} 2 \mathrm{aa062} \mathrm{cea} 79 \& \mathrm{ei}=5087 \% 0 \mathrm{~A}$ (Accessed 2006.09.23).

7 M-B Õhman, "On visible spaces and invisible peoples in Sweden and Tanzania" in JWN Tempelhoff (ed.), African water histories: transdisciplinary discourses, (NorthWestern University, Vanderbijlpark, 2005), pp. 185-226.

8 See for example, B Derman, R Odgaard and A Sjaastad (eds.), Conflicts over land \& water in Africa, (James Currey, Michigan State University Press and University of KwaZulu-Natal Press, Oxford, East Lansing and Pietermaritzburg, 2007). 


\section{Outline}

In the discussion to follow attention will be given to the origins of water history as a subdivision of environmental history. The latter is an approach to history that has internationally become one of the more robust fields of investigation. Then the focus moves to some recent and contemporary trends in the field of water history in South Africa. The current emphasis on the historiography of water history in South Africa is the result of steady growth in the field - largely because of its relevance in a water-stressed subcontinent. In comparison to most other African states, the political transformation of the country as an indigenous African state was delayed for the greater part of the twentieth century. Following a period of international political and socio-economic isolation, it was only in the 1990s that this transition took place, literally catapulting South Africa into the international water studies environment. At present the country is partner to most continental and international initiatives in the field of water governance and management. And in the academic field of water studies too, it has made substantial progress. This discussion deals with the manner in which the discipline of history in South Africa has adjusted to these widespread changes.

\section{Water history and its linkage with environmental history}

Although the history of water has featured in many forms and under a variety of names for a long time,${ }^{9}$ the genealogy of the current flow of research - especially in the discipline of historical studies - is a by-product of the 1960s. It was at this time, in the United States of America, that Rachel Carson's groundbreaking study, Silent spring, ${ }^{10}$ was instrumental in bringing environmental politics to the fore as an important discourse in scientific scholarship. Although history traditionally has a strong political thread, the discipline did not at first feature prominently in debates on environmental politics. Environmental activism was most markedly promoted in the relatively new interdisciplinary field of environmental studies that was growing by leaps and bounds as thousands of first generation 'baby boomers' in the USA enrolled for interdisciplinary postgraduate studies at colleges and universities. Environmental studies, with a smattering of historical information, began to appear in the 1970s. ${ }^{11}$ By the

9 See LB Lee, "Water resource history: a new field of historiography?" in The Pacific Historical Review, 57(4), November 1988, pp. 457-467.

$10 \mathrm{R}$ Carson, Silent spring, (Hamish Hamilton, London, 1963).

$11 \mathrm{~N}$ Hundley, Jr, "Water and the West in historical imagination" in The Western Historical Journal, 27(1), Spring 1996, pp. 5-31. 
1980s, when water history themes featured in new research outputs, enthusiasm for promoting the cause of environmental politics had been relegated to a formalised sub-discourse in mainstream academic thinking. ${ }^{12}$ A number of exemplary works appeared at the time, but for water historians it was Worster's Rivers of Empire ${ }^{13}$ that caught the attention. The evolution of irrigation in the American West, beginning in the mid-nineteenth century, was responsible for a euphoric sense of progress which by the twentieth century had become a development nightmare because of the growing threat of dwindling water resources in some of the arid parts of the USA. Worster's description of the Dustbowl presented a very pointed environmental message to great effect. It was based on sound scholarship and was also of considerable literary value. ${ }^{14}$ Another influential work was Tarr and Melosi's book on urban environments and the management of pollution, which shed light on the history of water and how it has been used ever since the onset of American urban development. ${ }^{15}$ As early as the 1970s both these authors were at the forefront of opening up the potential of a focus on water in the discipline of environmental history.

In Western Europe and the United Kingdom, according to McNeil, the discipline of environmental history was slow to take off. ${ }^{16}$ However, it does appear that some important work had been done in the field of water history as early as the 1970s, with publications such as Stanbridge's multi-volume study on sewage treatment in Britain. ${ }^{17}$ Once research began there was soon a consistent flow of significant results. The development of environmental history, particularly in Britain, had an exponential effect in the British Commonwealth, of

12 JR McNeil, "Observations on the nature and culture of environmental history" in History \& Theory, Theme issue, 42, December 2003, p. 34.

13 D Worster, Rivers of empire: water, aridity and the growth of the American West, (Pantheon Books, New York, 1985).

14 LB Lee, "Water resource history: a new field of historiography?" in The Pacific Historical Review, 57(4), November 1988, p. 466.

$15 \mathrm{JK}$ Stine and J Tarr, "At the intersection of histories: technology and the environment" in Technology and Culture, 39(4), October 1998, pp. 614-615; See also CM Rosen, "Knowing' industrial pollution: nuisance law and the power tradition in a time of rapid economic change, 1840-1864" in Environmental History, October 2003, pp. 1-33 Reference No. 3 on p. 24 at http://findarticles. com/p/ articles/mi_qa3854/is_200310/ai_n9330335/pg_24 (Accessed 2008.06.15).

16 JR McNeil, "Observations on the nature and culture of environmental history" in History \& Theory, Theme issue, 42, December 2003, pp. 19-21.

$17 \mathrm{HH}$ Stanbridge, History of sewage treatment in Britain, (Institute of Water Pollution, Kent, 1976). 
which South Africa once again ${ }^{18}$ became part in $1994 .{ }^{19}$ In Canada, Australia and New Zealand, collaboration and exchanges between historians increased because they were better informed on developments in environmental studies. ${ }^{20}$ As of the 1990s, water history research became more relevant in view of the anticipated regional impact of global climate change. Much can be learnt from studies undertaken in Australia, which like South Africa is a waterstressed country. ${ }^{21}$

The history of technology has also been a major influence on the evolution of water history. ${ }^{22}$ Researchers in engineering sciences, in particular, have made a substantial contribution and will no doubt do so in the future, because of the contemporary relevance of links between past and present in the technologies of mineralogy, hydroelectricity, irrigation, digital data-capturing, as well as water supply and treatment systems. Historical studies have also been prominent in the fields of environmental, legal, health and management sciences that are currently an integral part of water

18 The country was part of the British Commonwealth between 1910 and 1960 when it was forced to leave as a result of the former government's apartheid policies.

19 See for example: S Dovers, R Edgecombe and B Guest (eds.), South Africa's environmental history: cases and comparisons, (Ohio University Press and David Philip Publishers, Ohio and Cape Town, 2003). Historians of South Africa, working overseas, such as $\mathrm{W}$ Beinart, have been exemplary in sharing many of the new trends in historical writing with colleagues in South Africa. See W Beinart, Twentieth century South Africa, (Oxford University Press, Cape Town and Oxford, 1994); W Beinart and P Coates, Environment and history. The taming of nature in the USA and South Africa, (Routledge, London, 1995).

20 JR McNeil, "Observations on the nature and culture of environmental history" in History \& Theory, Theme issue, 42, December 2003, pp. 22-25.

21 See for example T Griffiths and L Robin (eds.), Ecology and Empire: environmental history of settler societies, (Keele University Press, University of Natal Press, Pietermaritzburg, 1997);

22 This association is evident in the number of water history contributions in Technology and Culture, the journal of the Society for the History of Technology (SHOT), founded in the 1950s in the United States of America. The founding fathers' approach to this branch of historical studies, is evident in R Burlingame, "Technology: neglected clue to historical change" in Technology and Culture, 2(3), Summer 1961, pp. 219-229. Note on pp. 227-228 of this article the special attention given to a linkage between water and the history of transportation in the United States of America. Also see JK Stine and J Tarr, "At the intersection of histories: technology and the environment" in Technology and Culture, 39(4), October 1998, pp. 601-640. It is clear from this article that apart from Melosi's work, relatively little had been done until the mid-1990s in the cross fields of pollution, water and the environment. See for example how the history of water and history of technology dovetail in D Edgerton, The shock of the old: technology and global history since 1900, (Oxford University, Oxford, New York, 2007), Chapter 4. 
studies curricula at tertiary education institutions in all parts of the world.

On numerous occasions in recent years, the potential of water history has been put to the test in debates on fashionable issues such as Tony Allan's concept of 'virtual water ${ }^{23}$ and the 'water footprint'. ${ }^{24}$ Frequently such work was not by historians, but by specialists making use of history. History began to form an integral part of their discussions on issues such as the commodification of water, ${ }^{25}$ transboundary water catchment management, ${ }^{26}$ hydropolitics, ${ }^{27}$ and water wars. ${ }^{28}$ There appears to be consensus that historical studies is relevant in water research - especially in respect of critical thinking strategies that have traditionally been associated with the discipline. ${ }^{29}$

\section{Historiographical trends in South Africa}

In historiographical terms water history in South African is still a

23 T Allan, "Virtual water: a strategic resource. Global osculation to regional deficits" in Ground Water, 36(4), July-August, 1998, pp. 545-546; For a comparative study which features southern Africa, see T Allan, "Water resources in semi-arid regions: real deficits and economically invisible and politically silent solutions" in A Turton and R Henwood (eds.) Hydropolitics in the developing world: a Southern African perspective, (AWIRU, University of Pretoria, Pretoria, 2002), pp. 23-36.

$24 \mathrm{~F}$ Pearce, When the rivers run dry: what happens when our water runs out?, (Transworld Publishers, London, 2007), pp. 18-25. Also see the webpage of Water Footprint at http://www.waterfootprint.org/?page=files/home (Accessed 2008.07.02).

25 T Kluge, "Wasser ist Kultur" in Die Zeit, 13/2003 at http://www.zeit.de/2003/ 13/ST-Wasser; P. Bond, "An answer to marketization: decommodification and the assertion to rights to essential services" in Multinational Monitor 23, 7/8, Jul/ Aug 2002, pp. 14-7; A Versluis, "The Great Lakes as commodity. Water: public good or private gain" in Counterpunch, 2004.01.19 at http://www. counterpunch.org/verluis01192004.html

26 AR Turton, R Meissner, PM Mampane \& O Seremo, A hydropolitical history of South Africa's international river basins. WRC Report No. 1220/1/04. (Water Research Commission, Pretoria, October 2004).

27 M Musemwa, "'Disciplining a dissident city': hydropolitics in the city of Bulawayo, Matabeleland, Zimbabwe, 1980-1994" in Journal of Southern African Studies, 32(2), June 2006, pp. 239-254.

28 See R Glennon (ed.), Water follies: groundwater pumping and the fate of America's fresh waters, (Islan Press, Washington, 2002); M Reisner, Cadillac desert: the American West and its disappearing water, (Viking Press, New York, 1986); AT Wolf is one of the leaders in the field. See the Oregon State University's Department of geosciences website Transboundary freshwater dispute database at http:// www.transboundarywaters.orst.edu/ (accessed, 2008.04.15); For an introductory impression of levels of interaction between politics, history and water conflict see AT Wolf, "Conflict and cooperation along international waterways" in Water Policy, 1(2), 1998, pp. 251-265.

29 M Reuss, "Historians, historical analysis, and international water politics" in The Public Historian, 26(1), Winter 2004, pp. 65-79. 
young field. Quantitatively, output can hardly be compared to similar work in North America, Western Europe, Southeast Asia, North Africa and the Middle East. It is safe to state that there is currently a paucity of good research results. ${ }^{30}$ The reasons for this state of affairs form the backdrop of the following discussion.

Ever since the late-1960s there has been in South Africa a concerted effort to promote scientific research in the field of the water studies. ${ }^{31}$ Parliament's approval of the Water Research Act, No. 34 of 1971, was an affirmation of the need to promote research in fields of science that could be of value to the government's department of water affairs. The Water Research Commission (WRC) was a direct outcome of these developments. ${ }^{32}$ Unfortunately, history has traditionally been classified as part of the humanities/social sciences, and did not feature prominently. ${ }^{33}$ Then too, there were only slight indications of an awareness of environmental issues in water studies. ${ }^{34}$ Water history was clearly not in demand. Exceptions were the historical writing of professional and academic engineers such as Dr Bob Laburn at the Rand Water Board;35 Prof. Des Midgley, at the University

30 For a preliminary overview of historiographical trends in South African water history, see JWN Tempelhoff, “"n Historiografiese verkenning van watergeskiedenis" Koers, 70(3), 2005, pp. 473-514. The article takes a broad view of historiographical trends in the field and does not focus specifically on South Africa.

31 Practical training for professionals operating in the water sector dates back to 1937 with the founding of the Water Institute of South Africa (WISA). See Anon., "WISA has proud history" in IMIESA Yearbook 2004, May 2004, pp. 58-59.

32 JWN Tempelhoff, The substance of ubiquity: Rand Water 1903-2003, (Kleio Publishers, Vanderbijlpark, 2003), Chapter 8.

33 One of the pioneers in the field of environmental studies at the time was Prof. Richard Fuggle of the University of Cape Town. He also asserted considerable influence in promoting a greater awareness of water in the South African environment. See RF Fuggle Collision of rapprochement: environmental challenge in S. Africa, (University of Cape Town, Cape Town, 1974). For a general impression of the thinking on water and its relative position in the broader spectrum of disciplinary thought, see Republic of South Africa (RSA), Department of water affairs, Management of the water resources of the Republic of South Africa, (Department of water affairs, Pretoria, 1986). At most human geography seemed to enjoy acceptance in the hydrological environment of the department at the time.

34 See P Steyn, "Popular environmental struggles in South Africa, 1972-1992" in Historia, 47(1), May 2001, pp. 125-158; P Steyn, "Environmental management in South Africa: twenty years of governmental response to the global challenge" in Historia, 46(1), May 2001, pp. 25-53.

35 RJ Laburn ' $n$ Historiese oorsig oor watervoorsiening aan die Witwatersrand (Gepubliseerde eerste voordrag in ' $\mathrm{n}$ reeks gelewer aan die Johannesburg Historical Society op 26 Augustus 1970), (Walker \& Snashall, g.p., g.d.); RJ Laburn, The Rand Water Board 75 1903-1978: a treatise on the Rand Water Board with specific reference to its responsibilities achievements and policies during 75 years of operation, (Rand Water Board, Johannesburg, February 1979). 
of the Witwatersrand; 36 a literary commemorative work for the Water Year by FA Venter; ${ }^{37}$ a chapter by the inveterate conservationist TC Robertson in a volume on South Africa's natural heritage, edited by Andries du Plessis; ${ }^{38}$ and some work of the environmental journalist, James Clarke. ${ }^{39}$ Apart from these publications, water history did not feature prominently in the world of South African letters. The cohesive factor in these studies was the unmistakable consensus that water deserved attention in appraisals of the South African environment of the 1970s. It was not activist in style, but merely informative. These authors had clearly been influenced by the popularity of environmentalism and environmental consciousness in Western Europe and the United States of America. They then used the discursive approach to historical writing to convey their impressions of the aquatic realm to South African readers.

The absence of professional historians in water research was the result of external (international) circumstances and internal (national) politics. Mainstream historical writing until the late-1980s was an important battleground for the struggle against the apartheid policies of the former National Party government. ${ }^{40}$ While a section of the historical fraternity had been internationally isolated for their tacit support of the government's policies, revisionist and Africanist historians, working in the then fashionable paradigm of neo-Marxist thought, as well as the popular History Workshop Movement, provided substantial momentum to initiatives aimed at bringing to an end the racial policies of the day. In essence it was a debate between liberal historians, revisionist historians (mostly neo-Marxists and structuralists) and Afrikaner nationalist historians. Liberal historians tended to outline the fallacies of race issues in South Africa. The revisionists wanted to redefine the prevailing historical discourse by optimising class, labour and capital in a framework that could

36 See for example his brief, but insightful historical observations in D Midgley, "Water resources - the Southern African picture" in G Baker (ed.), Resources of Southern Africa: today and tomorrow: proceedings of a conference held by the Associated Scientific and Technical Societies of South Africa at Johannesburg, (The Associated Scientific and Technical Societies of South Africa, Johannesburg, 1976).

37 See, for example: FA Venter, (ed.), Water, (Afrikaanse Pers-Boekhandel, vir die ministerie van waterwese, Pretoria, c. 1971-2); Hobbs, LD and RF Phelines (eds), Water 75 (Erudita Publications, Ferreirasdorp, n.d.).

38 TC Robertson, "Water" in A du Plessis (ed.), The conservation of our heritage, (Human $\&$ Rousseau, Cape Town and Pretoria, 1974), pp. 173-236.

39 J Clarke, Our fragile land: South Africa's environmental crisis, (Macmillan, Johannesburg, 1974).

40 C Saunders, "Four decades of South African academic historical writing: a personal perspective" in HE Stolten (ed.), History making and present day politics: the meaning of collective memory in South Africa, (Nordiska Afrikainstitutet, Uppsala, 2007), pp. 280-291. 
accommodate much of the prevailing Africanist historical thought. Afrikaner nationalist historians, in turn, tended to favour an ethnic approach in which Afrikaner interests appeared to dominate the history of South Africa. ${ }^{41}$ History classrooms at universities were crammed with large numbers of students, eager to learn more of the country's racial past. Methodologically the liberal and revisionist approaches, by far the strongest groupings of the three, tended to have a close association with social history and its dominant methodological discourse of the 1970s and 1980s. Historians working in this paradigm were also more aware of international trends in the discipline. To all intents and purposes the liberal and revisionist historians were basically concentrating on political history.

A clear historiographical discrepancy is discernable if a comparison is drawn between trends in the discipline in the United States of America and South Africa. The American Society for Environmental History, the first of its kind in the world, was founded in 1975 - in the aftermath of the Vietnam War. At the time the South African government faced increasing pressure for the formal recognition of trade unions of colour which would bring an end to racial discrimination in the workplace. ${ }^{42}$ Historians accordingly focused on the social history of labour in South Africa. A decade later, when Donald Worster urged American environmental historians to look beyond the divide between the history of nature and the history of culture ${ }^{43}$ thousands of black South Africans were protesting in the townships, making the country ungovernable. At the time the most influential historians in South Africa were transmitting the latest research findings in the field of popular people's history (and struggles)

41 For more on this see C Saunders, The making of the South African past: major historians on race and class, (David Philip, Cape Town, 1988); C Saunders, Writing history: South Africa's urban past and other essays (Human Sciences Research Council, Pretoria, 1992); FA van Jaarsveld, Afrikanergeskiedskrywing: verlede, hede en toekoms (Lex Patria, Johannesburg, 1992); FA van Jaarsveld, The Afrikaner's interpretation of South African history, (Simondium, Cape Town, 1964); FA van Jaarsveld, Geskiedkundige verkenninge, (Van Schaik, Pretoria, 1974); HM Wright, The burden of the present: liberal-radical controversy over southern African history (David Philip, Cape Town, 1977); K Smith, The changing past: trends in South African historical writing (Southern, Johannesburg, 1988). For a more recent historiographical study with substantial merit, see HE Stolten (ed.), History making and present day politics: the meaning of collective memory in South Africa, (Nordiska Afrikainstitutet, Uppsala, 2007)

$42 \mathrm{~J}$ Sithole and S Ndlovu, "The revival of the labour movement, 1970-1980" and D Hemson, M Legassick and N Ulrich, "White activists and the revival of the workers' movement" in SADET, The road to democracy in South Africa, 1970-1980, Volume 2, (University of South Africa Press, Pretoria, 2006), pp. 187-242 and 243-314.

43 D Worster, "History as natural history: an essay on theory and method" in The Pacific Historical Review, 53(1), February 1984, pp. 1-19. 
to South Africans at grassroots level. ${ }^{44}$ Meanwhile, the government was trying to address Cold War issues and win friends in the West by waging border wars against national liberation fighters in Namibia, Zimbabwe, Tanzania, Mozambique and Botswana.

With the exception of a small number of specialists in the field of local and regional history, water did not register on the radar screens of historians. In general terms relevant information on the history of urban water supply management was located in the local, urban and regional historiography of South Africa. This genre enjoyed a long tradition of amateur dominance until historians at Rhodes University promoted active research and the division for historical studies at South Africa's Human Sciences Research Council (HSRC), founded Contree, a peer reviewed journal aimed at promoting interest in local and regional history. Despite its relatively chequered path until the late-1960s academic local and urban history now had a marked focus on interdisciplinary history. There were also some works which had leanings towards the Annales School of historians. ${ }^{45}$ Interestingly, it was also an area where collaboration began between South African historians of different political persuasions. In the interest of local and regional history, many historians chose to set aside their political differences and share insights on common research interests. ${ }^{46}$ This collaboration gave a degree of respectability to local and regional history and opened up the way for the integration of liberal (Englishspeaking) and conservative (Afrikaans-speaking) approaches to the discipline. In many of the articles, water featured as an element for understanding the history of local and regional environments.

The first sign of change was evident in the second half of the 1980s when Kevin Shillington, noted for his revisionist works, published his research on the Vaalharts irrigation scheme. ${ }^{47}$ His chapter was

44 See HE Stolten, "History in the new South Africa: an introduction" in HE Stolten (ed.), History making and present day politics: the meaning of collective memory in South Africa, (Nordiska Afrikainstitutet, Uppsala, 2007), pp. 5-50.

45 The Annales school of historians emerged at the start of the twentieth century in the France and were notable for a strong social economic approach in which geography and Marxist theories of historical materialism featured prominently. The Annales approach was fashionable in all parts of the world until the late1970 s. They have also asserted a substantial influence on water historiography and its methodologies.

46 See JWN Tempelhoff, The challenge of regional en local history in South Africa (University of Zululand Publication series B79, Kwadlangeswa, 1990).

$47 \mathrm{~K}$ Shillington, "Irrigation, agriculture and the state: The Harts Valley in historical perspective" in W Beinart, P Delius \& S Trapido (eds.), Putting a plough to the ground: accumulation and dispossession in rural South Africa, 1850-1930, (Ravan Press, Johannesburg, 1986), pp. 311-335. 
not environmental in orientation, but instead explored the subject of irrigation as an extension of historical racial discrimination in the country's farming sector. Although relatively brief, it was nevertheless a significant contribution. Since the 1940s, earlier works, primarily by geographers, tended to underscore the heroic accomplishments of irrigation in South Africa ${ }^{48}$ - a tendency that was to persist for some time to come ${ }^{49}$ A response to Shillington's ideas only came from De Jager and Marais in the 1990s; they delved into the prehistory of the scheme, pointing to its firm roots in colonialist thought on development. ${ }^{50}$ They were writing in the tumultuous era of South Africa's political transition to a multi-racial democracy and their work thus lost much of its potential impact. Furthermore, in this study there was no trace of environmental and/ or technology history. It was more in the nature of a response to what had been written by Shillington. The authors accentuated the fact that the political exclusion of Africans in the irrigation developments at Vaalharts, pre-dated the apartheid era - a debate that had already been opened by Lubbe in the 1960s. ${ }^{51}$

\section{Developments since the 1990s}

In broad perspective, the 1990s were dismal years for the discipline of history. The country's political liberation shifted the focus to the public sphere of active, socio-economic and political transformation. The discipline was also influenced by comprehensive changes in education policies. In terms of outcomes based education (OBE) history, as an independent discipline, only featured as an elective major in the later phases of secondary school curricula. Previously it had been an integral part of primary and secondary education as a formative and independent discipline. In the new political dispensation the nature and content of historical studies changed overnight. On the tertiary level in departments of history at the 23 universities in the country, student enrolments dropped

48 See for example the following on the Vaalharts project: SJ Lubbe, Die geografiese aspekte van die Vaalbankdam; en van die Vaalhartsbesproeiingsprojek, (MA, Universiteit van Pretoria, 1942); JC Kotze, Die Vaalhartsbesproeiingskema - ' $n$ ekonomiese en sosiaal-geografiese studie, (MA Universiteit van Stellenbosch, 1961).

49 See H Bornman, Vaalharts, (Vaalharts Halfeeufeeskomitee, Vaalharts, 1988); P Louw, Vaalharts besproeiingskema: ontstaan en ontwikkeling, (No publisher or place of publication c. 1980s); HG van der Westhuizen, Hervormde Kerk halfeeu op Vaalwater 1940-1990, (Ned. Herv. Gemeente, 1994); Anon., Vaalharts koöperasie beperk 50 jaar 1944 tot 1994, (Promedia, Vaalharts, 1994).

50 AMvA de Jager en AH Marais, "Die aanloop tot die Vaalhartsbesproeiingskema" in Journal of the South African Institute of Civil Engineers, 36(1), 1994, pp. 6-12.

51 SJ Lubbe, Die geografiese aspekte ..., pp. 188-196. cf above note 48 
significantly. Many teaching historians either went into early retirement or moved to different fields of academic endeavour. ${ }^{52}$ This changed perspective on the discipline of history was partly the result of new policies introduced in higher education in South Africa, aligning the country with trends in other parts of the world. It was also to some extent the product of the new dominant discourse on the country's past. The history of the country had to be rewritten in such a manner that all South Africans featured, especially those of colour, who had previously been sidelined and even ignored. The liberation struggle and the triumphant road to democracy now took centre stage. In essence, it was only the first phase in a dialectical process of historiographical revision that would see debates conducted in a variety of fields between historians and the public at large. The country's history has remained, up to the present, a strongly contested field of debate between all and sundry on issues of ideology and race.

Against this backdrop historians actively started working on the critical re-consideration of their discipline. It is here that water history began to emerge. Shell and Guelke conducted an investigation into the exploitation of indigenous people on the frontiers of the Cape Colony and examined how the whites had pirated their knowledge of the environment to locate water sources in the arid interior of southern Africa. ${ }^{53}$ Perhaps fittingly at the time, the urban water history of Cape Town made significant progress. Grant's findings on the history of water in Cape Town between 1840 and $1920^{54}$ informed concurrent research at the University of Cape Town on this new focus in the historiography of South Africa's mother city.

Traditionally, the history of irrigation in South Africa was an important field of scholarship, and popular history. ${ }^{55}$ It formed part of the

52 See G Verbeeck "Die wraak van vergifnis: moraliteit, geskiedskrywing en politiek in Suid-Afrika" in Historia, 52(2), November 2007, pp. 239-266; C Saunders, "South Africa's racial past: the history and historiography of racism, segregation and apartheid" Paul Maylam: book review in South African Historical Journal, 47, 2002, pp. 238-241; JWN Tempelhoff, Verhuidiglikte verlede: aspekte van die hermeneutiese benadering tot die geskiedenis, (Kleio, Vanderbijlpark, 2002); JWN Tempelhoff, "Historiografie en stilistiek: die verkenning van enkele kontemporêre tendense" in Journal for Contemporary History, respectively in 28(1) June 2003 and 28(3), December 2003, pp. 92-113 and 110-122.

53 L. Guelke and R. Shell, "Landscape of conquest: frontier water alienation and Khoikhoi strategies of survival, 1652-1780" in Journal of Southern African Studies, 18(4), December 1992, pp. 803-24.

54 D Grant, The politics of water supply: the history of Cape Town's water supply 1840-1920 (MA, UCT, 1991).

$55 \mathrm{~J}$ Meiring, Sundays River Valley: its history and settlement, (Balkema, Cape Town, 1959); J Burman, Waters of the Western Cape, (Human \& Rousseau. Cape Town 1970) 
pioneering history of life in southern Africa - one of the 30 driest regions of the world. It was also part of twentieth century socioeconomic history in which poor whitism, ${ }^{56}$ missionary history ${ }^{57}$ and the local history of rural settlements ${ }^{58}$ featured prominently. Legassick, working on Upington, ${ }^{59}$ re-introduced irrigation history. This time the focus was on the process of land claims and restitution in the Northern Cape. ${ }^{60}$ It formed an interesting sub-discourse in the prevalent economic debate on the redistribution of wealth in the new multi-racial, democracy. Researched and written at the time of the 1994 transition from an old to a new South Africa, Legassick's work highlighted the relevance of irrigation and the manner in which it directly and indirectly shaped the lives of humans in society. People of colour, according to him, had been exploited for their labour in the construction of irrigation schemes and in the process had lost possession of the land on which they had been resident. Another contemporary publication was that by Jacobs who undertook research on the history of irrigation and water management at Kuruman. ${ }^{61}$ She provides an exposition of how indigenous people were systematically driven away from the eyes of local springs, cutting local communities off from water supplies until they were forced by circumstances to either leave or become subservient to white residents. A similar picture of land dispossession on the basis of race emerged from this study. This seminal work has contributed to Nancy Jacobs's status as one of the pioneers of environmental justice in South African environmental historiography. ${ }^{62}$

In the mid-1990s a new legal framework for water in South Africa was under intense debate. The existing legislation, dating back to

56 H Coetzee, Verarming en oorheersing, (Nasionale Pers, Bloemfontein, Kaapstad en Port Elizabeth, 1942); R Morrell (ed.), White but poor: essays on the history of poor whites in Southern Africa 1880-1940, (University of South Africa, Pretoria, 1992).

$57 \mathrm{~W}$ Beinart, The rise of conservation in South Africa: settlers, livestock, and the environment 1770-1950, (Oxford University Press, Oxford, 2003), p. 178.

58 PJ Rossouw, "Die arbeidskolonie Kakamas" in Archives Yearbook for South African history, 14(2), 1951, (Staatsdrukker, Parow, n.d.)

59 M Legassick, "The will of Abraham and Elizabeth September: the struggle for land in Gordonia, 1898-1995" in The Journal of African History, 37(3), 1996, pp. $371-418$.

60 M Legassick, "Claiming land and making memory: engaging with the past in land restitution in $\mathrm{HE}$ Stolten (ed.), History making and present day politics: the meaning of collective memory in South Africa, (Nordiska Afrikainstitutet, Uppsala, 2007), pp. 129-147.

61 N Jacobs, "The flowing eye: water management in the Upper Kuruman Valley, South Africa, c. 1800- 1962" in The Journal of African History, 37(2), 1996, pp. 237-260.

62 N Jacobs, Environment, power and injustice: a South African history, (Cambridge University Press, Cambridge, 2003). 
1956, was out of step with the requirements for a new multiracial democratic society with the approach of the new millennium. ${ }^{63}$ Water was high on the agenda of the African National Congress (ANC) government's Reconstruction and Development Program (RDP). ${ }^{64}$ In terms of the new constitution of South Africa, approved in 1996, access to clean drinking water was singled out as a basic human right. ${ }^{65}$

In the next two years South Africa's Water Services Act, No. 108 of 1997 and the National Water Act, No. 36 of 1998 were approved by parliament. A complex transformational process was set in motion to implement the third comprehensive revision of the country's water sector since the formation of the Union in 1910. In the first era, following the implementation of the Irrigation and Conservation of water Act, No. 8 of 1912, the focus had been on using water for creating welfare and promoting industry. The second era, that of the Water Act, No. 54 of 1956, was notable for South Africa's remarkable economic development. The attention was focused on creating sufficient water supplies to keep abreast with demand. The latest framework, implemented since the 1990s, has focused extensively on issues such as: water demand management, instead of merely providing costly, ineffective and unsustainable storage facilities; a distinct concern for the environment; respecting access to clean drinking water as a basic human right in a society where the majority of the population had formerly been deprived of adequate water supply and sanitation on racial grounds; and finally, the awareness that water has become a finite resource that needs to be managed in a sustainable manner.

At the time of planning the new legislation there was very little in the way of historical research on water to inform the policy makers of the day. ${ }^{66}$ For example, the work on sanitation and health by Swanson $(1977)^{67}$ and that by Unterhalter $(1982)^{68}$ could shed some relevant

63 RSA, White paper on water supply and sanitation, 1994.

64 Republic of South Africa (RSA), A history of the first decade of water service delivery in South Africa 1994-2004: meeting the millennium development goals, (Department of water affairs and forestry (DWAF), Pretoria, c. 2006-7), pp. 4-7.

65 See Constitution of the Republic of South Africa, No 108 of 1996, Ch2 subsection 27.

66 RH Thomas, Quality and quantity: the search for an adequate, and pure supply of water for Pietermaritzburg, (B.A. Hons. assignment, University of KwaZulu-Natal, Pietermaritzburg, 1991); WNK Hickson, Springs of clear water: a history of Uitenhage water, (Simon van der Stel Foundation, Uitenhage, 1989).

67 MW Swanson, "The sanitation syndrome: bubonic plague and urban native policy in the Cape Colony, 1900-1909" in The Journal of African History, 18(3), 1977, pp. 387-410.

68 B Unterhalter, "Inequalities in health and disease: the case of mortality rates for the city of Johannesburg, South Africa, 1910-1979" in International Journal of Health Services, 12(4), 1982, pp. 617-636. 
light. And in the field of water supply and management there was Wall's 1980s experiment, with the idea of a 'new history' for South Africa, focusing in on the history of water resources. ${ }^{69}$ There was also Crosser's master's study on the evolution of the public water supply of Johannesburg from a private to a public sector service in the period 1886-1906, ${ }^{70}$ while in the field of technology history, Grant and Flinn reported, in passing, on the history of sanitation and water supply in Johannesburg. ${ }^{71}$

A notable feature of the work that had been done up to the late 1990s was that they were all essentially micro-histories. No comprehensive overview (grand narrative) of South Africa's water history was available. Despite all the shortcomings, however, the information was important for a critique of the country's 'pre-1994' water service structures. ${ }^{72}$

By 1999 it seemed as if the long dry spell in water historiography was finally coming to an end. Wall wrote on the comparative history of water management. ${ }^{73}$ Murray, a city engineer by profession, was busy researching the water history of Cape Town and by 2001 his work had culminated in a respectable working document. ${ }^{74}$ This project, which is currently (2008) a collaborative initiative under the auspices of Southern Water, the National archives repository in Cape Town and the University of Cape Town, promises to eventually become one of the most comprehensive histories (in timeframes) of any city in South Africa. ${ }^{75}$ The need for urban water histories, up to the present, remains crucial. For example, the first detailed water history research

$69 \mathrm{~K}$ Wall, "A new history of South Africa from a water resources viewpoint" in The Civil Engineer in South Africa, May 1983, pp. 265-271.

70 EM Crosser, Water supply and utilization in Johannesburg 1886-1905 (MA, University of the Witwatersrand, Johannesburg, 1987).

71 G Grant and T Flinn, Watershed town: the history of the Johannesburg city engineer's department, (Comma Print \& Design, Johannesburg, 1992).

72 See, for example, R Bate and R Tren, The Cost of Free Water: the Global Problem of Water Misallocation and the Case of South Africa, (The Free Market Foundation, Johannesburg, 2002).

$73 \mathrm{~K}$ Wall, "Water, civil engineers and multipurpose metropolitan government for the old Cape Peninsula municipalities: technical paper" in Journal of the South African Institute of Civil Engineers, 40(3), 1998, pp. 1-8.

74 T Murray, "Much water under many bridges: the history of the catchments, rivers, and organic draining systems of greater Cape Town", (Work in progress, Rondebosch, Cape Town, 2001).

75 S Matthews, "Tracing Van Riebeeck's footsteps: water resources management" in Water Wheel, 6(6), December 2007, pp. 12-15. 
on Bloemfontein since $1960^{76}$ was published by Botes in $2001 .^{77}$ Zangel's study on Johannesburg's water opened up new discourses in water history with a unique accent on post-1994 policy objectives such as poverty, housing and proper sanitation. ${ }^{78}$ Although she primarily worked in the field of social history, there was also a focus on environmental history. Another important project, currently in the process of completion, is Mäki's comparative history of urban water supply, health and sanitation in four South African cities. ${ }^{79}$ This Finnish initiative should be of great value to water historians of Africa. The author's research group at the University of Tampere has for some time been involved in extensive collaborative water history research in Africa.

The new millennium also saw work produced in the field of health and sanitation. Carruthers wrote a brief but eloquent environmental history of the Delta wastewater treatment works that served parts of Johannesburg from the 1930 s to $1963 .^{80}$ More recently Parnell touched on sanitation issues in her study on the slum-yards in downtown Johannesburg. ${ }^{81}$ Phatlane's 2006 study on poverty, health and disease in the apartheid era, also focused on diseases related to poor living conditions and a lack of sanitary services in the former African 'homeland' residential areas of South Africa. ${ }^{82}$

The environmental justice approach to water history currently tends to be well suited to regional history. Van Eeden's work, in partnership with natural scientists, activists and journalists on the de-watering of sinkholes in the Carletonville area of Gauteng, ${ }^{83}$ marked the beginning of a more comprehensive, ongoing regional project on the

$76 \mathrm{MCE}$ Van Schoor, and JJ Oberholster, "Die fontein van Bloemfontein - voorstelle vir "n monument" in Historia, 5(3), September 1960, pp. 169-178.

77 SM Botes, "Die stoommeule en bierbrouery op die terrein van Fort Drury, Bloemfontein, 1868-1920" in Suid-Afrikaanse Tydskrif vir Kultuurgeskiedenis, 15(2), November 2001, pp. 1-20.

78 VA Zangel, 'The seething masses'- housing, water and sanitation in the lives of Johannesburg's poor 1886-1906, (MA, North-West University, Vanderbijlpark, 2004).

$79 \mathrm{H}$ Mäki, Water, sanitation and health: the development of the environmental services in four South African cities, 1840-1920, (PhD, Tampere University, Finland, June-July 2008).

$80 \mathrm{~J}$ Carruthers, "From sewage sludge to pleasant park: the story of Delta disposal works, 1934-1963" in R Vermont (Consulting editor), Delta Environmental Centre: the first twenty-five years 1975-2000 and the road ahead, (Electronic publication, 2000 at http://www.deltaenviro. org.za/background/25years_sewage.htm1 (accessed April 2008).

81 S Parnell, Power and urban control: Johannesburg's inner city slum-yards, 19101923" in Journal of Southern African Studies, 29(3), September 2003, pp. 615-637.

82 SN Phatlane, Poverty, health and disease in the era of high apartheid: South Africa, 1948-1976, (PhD, University of South Africa, 2006).

83 ES van Eeden, B de Villiers, H Strydom and L Stoch "Effects of dewatering and sinkholes on people and environment - an analysis of the Carletonville area in Gauteng, South Africa" in Historia, 48(1), May 2003, pp. 95-125. 
Wonderfonteinspruit in North West Province and parts of Gauteng. ${ }^{84}$ This strain of historiography is contemporary in focus, ${ }^{85}$ but also relates to an approach to the discipline, known as a history of the present. ${ }^{86}$ Typical themes that are investigated tend to have a strong message of environmental justice ${ }^{87}$ and seek strategies to clean up pollution caused by industry, particularly the mining sector. ${ }^{88}$ The collapse of local and regional water treatment infrastructure has also received attention. ${ }^{89}$ It is in this context that civil society becomes a major actor and participant in research initiatives.

In the cultural and technological history of water, Staples' study on the mills of southern Africa ${ }^{90}$ was a continuation of outstanding work that had been done earlier by James Walton. ${ }^{91}$ A new contributor to the historiography of water technology in South Africa is the University of Johannesburg civil engineer, Johannes Haarhoff. He completed his postgraduate studies in the discipline of history and has subsequently worked on the desalination of water and water supply on ships of the Dutch East India Company (DEIC) in the seventeenth and eighteenth century. ${ }^{92}$ He has also collaborated with Finnish water historians on a comparative history of urban wells and toilets in South Africa and Finland ${ }^{93}$ and has been at the helm of a collaborative

84 See ES van Eeden, "Some human actions in the destruction and construction of culture and nature - the Merafong region as a case study" in TD The Journal for Transdisciplinary Research in Southern Africa, 2(2) December 2006, pp. 409-430.

85 A Turton "Can we solve tomorrow's problems with yesterday's experiences and today's science?" The Des Midgley memorial lecture, at the 13th SANCAHS Symposium, Cape Town, 6 September 2007.

86 For more in this respect see JWN Tempelhoff, V Munnik and M Viljoen, "The Vaal River Barrage, South Africa's hardest working water way: an historical contemplation" in TD The Journal for Transdisciplinary Research in Southern Africa, 3(1), July 2007, pp. 107-134.

87 See EJ and JWN Tempelhoff, "A story of two dams: government, industry and civil society in north-eastern South Africa 1994-2007" in New Contree, 53, May 2007, pp. 31-55.

88 EJ and JWN Tempelhoff, "The community, industry and the quest for a clean Vaal River 1997-2004" in S Hood-Washington, P Rosier and H Goodall (eds.), Echoes from the Poisoned well: global memories of environmental injustice, (Lexington Publishers, United States of America, 2006).

89 JWN Tempelhoff, Civil society and sanitation hydropolitics: a case study of South Africa's Vaal River Barrage (2008, forthcoming).

90 CO Staples, Mills of Southern Africa: water, wind and horse, (Umdaus Press, Hatfield, 2006).

$91 \mathrm{~J}$ Walton, Water-mills, windmills and horse-mills of South Africa, (C Struik, Cape Town, 1974).

$92 \mathrm{~J}$ Haarhoff, "Water and beverages on DEIC ships between the Netherlands and the Cape: 1602-1795" in Historia, 52(1) 2007, pp. 127-154.

93 J Haarhoff, P Juuti and H Mäki, "A short comparative history of wells and toilets in South Africa and Finland" in TD The Journal for Transdisciplinary Research in Southern Africa, 2(1), July 2006, pp. 103-130. 
initiative on the history of water transfer technology to Gauteng..$^{94}$ In the field of the cultural history of water, Gouws recently completed research on domestic water supply and sanitation in the rural pioneer Highveld home in the period 1840-1910. ${ }^{95}$ This study sheds light on the manner in which water technology was transferred from the urban to the rural domestic environment in the nineteenth and early twentieth century. It forms part of a more comprehensive project that is currently under way on the history of the Vaal River. ${ }^{96}$ The recent WRC publication, Our water our culture: a glimpse into the water history of the South African people, also provides some valuable overviews on South Africa's water history from a cultural and anthropological perspective. ${ }^{97}$

An important social science project of the Water Research Commission since 2000 has been the hydropolitical history of transboundary water in southern Africa. ${ }^{98}$ Turton, formerly of the University of Pretoria, and currently at South Africa's Council for Scientific and Industrial Research (CSIR), led the project, which was notable for its vast trajectory of sub-continental water research work aimed at incorporating the theoretical approaches of the political science concept of hydropolitics. Hydropolitics, first pioneered by Waterbury in the Middle East, ${ }^{99}$ has become a popular field of research for water historians. The Zimbabwean historian, Muchaparara Musemwa, working in South Africa, has also recently produced research results in the field. ${ }^{100}$

Related to hydropolitical history is research on big dam projects. The Lesotho Highlands Water project (LHWP), completed in 1996, is one

$94 \mathrm{~J}$ Haarhoff and JWN Tempelhoff, "Water supply to the Witwatersrand (Gauteng) 1924-2003" in Journal for Contemporary History, 32(2), December 2007, pp. 95114.

95 C Gouws, Water en sanitasie in die landelike Hoëveldse woning 1840-1910: 'n kultuurhistoriese studie, (MA, North-West University, Vanderbijlperk, 2007).

96 See JWN Tempelhoff, "Water and the human culture of appropriation: The Vaal River up to 1956" in TD The Journal for Transdisciplinary Research, 2(2), December 2006, pp. 431-452.

97 L van Vuuren (ed.), M Nel, S van Damme and E Braune, Our water our culture: a glimpse into the water history of the South African people, (Water Research Commmission, Pretoria, 2007).

98 AR Turton, R Meissner, PM Mampane \& O Seremo, A hydropolitical history of South Africa's international river basins. WRC Report No. 1220/1/04. (Water Research Commission, Pretoria, October 2004).

99 JWN Tempelhoff, "'n Historiografiese verkenning van watergeskiedenis" Koers, 70(3) 2005, p. 493.

100 M Musemwa, "Disciplining a dissident city': hydropolitics in the city of Bulawayo, Matabeleland, Zimbabwe, 1980-1994" in Journal of Southern African Studies, 32(2), June 2006, pp. 239-254; M Musemwa, Struggles over water: the history and politics of urban water supply services in Makokoba township, Bulawayo, Zimbabwe, 1894-1992, (PhD, University of Minnesota, 2003). 
of the major water schemes in Africa and initially attracted favourable comment. However, by the early 2000 s critical scholarship on the scheme was evident in the work of Thabane, who pointed to the effects of what appears to have been the indiscriminate relocation of people from for the construction site of the Mohale Dam. ${ }^{101}$ There has also been work by Bracking, who reported on corrupt practices in the project, ${ }^{102}$ and subsequently there has also been negative comment in the scholarship of Mwangi. ${ }^{103}$ This research suggests that the history of transnational hydropolitics will still feature for some time to come on the agenda for researchers of southern African water history. Linked to work on the LHWP is the history of major hydro-electricity schemes, such as the Grand Inga ${ }^{104}$ and Cahora Basa facilities. ${ }^{105}$ Research on hydroelectric power generation is currently an important issue at a time of increasing power shortages, not only in South Africa but elsewhere on the continent. ${ }^{106}$ The historiography on hydropower and trans-boundary water supply systems in southern Africa presents a challenge to researchers. There is a wealth of themes that require exploration. For example, there are interesting international and local debates on the impact of hydro-electrical technology on the aquatic environment. It seems as if the advantages and disadvantages of hydropower will in the not too distant future be weighed up against the alternative of nuclear power generation. In the process, the desirability of large dams can be opened for discussion again, as was the case in the 1990s and early 2000s when extensive international deliberations were the order of the day, under the auspices of the

101 M Thabane, Shifts from the old to new social and ecological environments in the Lesotho Highlands Water scheme: relocating residents of the Mohale Dam area" in Journal of Southern African Studies, 26(4), December 2000, (Special issue on African environments: past and present), pp. 633-654.

102 S Bracking, "The Lesotho Highlands corruption trial: who has been airbrushed from the dock?" in Review of African Political Economy, 28(88), Special issue on Africa's future: that sinking feeling, June 2001, pp. 302306.

103 O Mwangi, "Hydropolitics, ecocide and human security in Lesotho: a case study of the Lesotho Highlands Water Project" in Journal of Southern African Studies, 23(1), March 2007, pp. 3-17.

104 See SJ Wachter, "Giant dam projects aim to transform African power supplies" in International Herald Tribune, 2007.06. at http://www.iht.com/ articles / 2007/06/19/business/rnrghydro.php

105 UNEP, Africa: atlas of our changing environment, (United Nations Environmental Programme, Nairobi, 2008), pp. 252-253.

106 For a contemporary impression of the history of the power outages in South Africa in early 2008, see JWN Tempelhoff, "Bloot ' $n$ vrees vir verval? ' $n$ Mentaliteitsgeskiedenis van kragonderbrekings in Suid-Afrika: JanuarieApril 2008", paper resented at the national conference of the South African Society for Cultural History, Pretoria, 16-7 May 2008. 
International Commission of Large Dams (ICOLD). ${ }^{107}$

\section{Looking towards the future}

From the discussion thus far it is evident that water history as a discipline has relied extensively on a variety of related fields in the study of water. This is most evident from the evolutionary development of the International Water History Association (IWHA), the disciplinary institution that has as the primary objective to promote the study of water history in the international domain. Water researchers in other parts of the world have been active in the field of water history for a many years. Networking was traditionally confined to academic societies that were seldom dedicated to the pursuit of specialised interests in water history. It was only in 1999 - as a result of the strongly expressed need for coordination - that the IWHA was founded in Wales. ${ }^{108}$ The society currently has about 700 members. Not all are historians. Most participants at the biennial conferences of the association have been trained in other disciplines. What binds members together are two basic issues: locating sources of knowledge on water in the past; and using history as a primary or secondary vehicle for the better understanding of the water realm. Judging from attendance trends at IWHA conferences (held thus far in Bergen (2001), Alexandra (2003), Paris (2005) and Tampere (2007)) there is a lively interest in the field. The IWHA is perhaps one of the most important institutional structures at our disposal to promote greater cohesion and constructive debate on the nature of water history and trends for future development.

Similarly, in sub-Saharan Africa the field of past perspectives on water has generated wide interest. African researchers and their African Studies counterparts have not been idle. The Drakensberg conference of 2008, under the auspices of the IWHA, the South Africa's Water Research Commission (WRC) and North-West University (NWU), was the second conference of its kind since 2004 in sub-Saharan Africa. Indications are that the field of specialisation in water history on the continent is alive and well. ${ }^{109}$ It only requires more encouragement and a greater commitment to communication between researchers.

Currently there is a need for greater transdisciplinary research in

107 For more on this visit the website of the International Commission of Large Dams (ICOLD) at http://www.icold-cigb.net/pagearticle.aspx?ssmenu=210\#

108 M Reuss, "Historians, historical analysis, and international water politics" in The Public Historian, 26(1), Winter 2004, pp. 65-79.

109 A number of the papers presented at the conference were subsequently published in a book. See JWN Tempelhoff (ed.), African water histories: transdisciplinary discourses, (North-West University Vanderbijlpark, 2005). 
southern Africa. In the field of contemporary water studies it is important for historians in the region, in collaboration with water specialists who are interested in water history, to seek closer collaboration. A sound example of this nature is recent work conducted by Lumby, an economist and economic historian, who has collaborated with Matete and Rwelamira on aspects of water management history as part of a project for the Southern African Development Community (SADC). ${ }^{110}$

Many conventional historians still pursue their discipline from a tradition of writing critical narrative history with a strong accent on individualised interpretations, methodologically rooted in the framework of the classical hermeneutic approach. These historians have a valuable role to play and their particular approach to water history should be respected when they participate in collaborative projects. ${ }^{111}$ This will serve to prevent potential misunderstanding and acrimony. At the same time, in an era when the study of water history as a discipline has become varied and multi-faceted, historians need to explore the potential of multi-disciplinary collaboration, to open up new frontiers and new methods in the field. Theoretical work in Europe, such as that of Kaivo-oja, Katko and Seppälä, ${ }^{112}$ aimed at linking history and futures studies in research, is an example of what would typically pass for hydrohistory in contemporary collaborative research initiatives. Currently UNESCO's International Hydrological Programme (IHP) tends to support the shift to ecohydrology - an area that takes particular note of ecology (environment) in the study of hydrology-related research. ${ }^{113}$ The approach of being open to transdisciplinarity and Mode II-trends, as is the case in tertiary-level teaching and research in many parts of the world, suggests that history as a discipline will continue to develop as part of a discourse that is intended to generate research results that are relevant to society. ${ }^{114}$

110 A Lumby, M Matete and J Rwelamira, "The management of South Africa's water resources, with paticular reference to the period 1956-1998" in The South African Journal of Economic History, 20(2), September 2005, pp. 83-108.

111 For some insight into difficulties that can emerge, see M Reuss, "Historians, historical analysis, and international water politics" in The Public Historian, 26(1), Winter 2004, pp. 65-79.

112 YJ Kaivo-oja, TS Katko and OT Seppälä, "Seeking convergence between history and futures research" in Futures, 36(5) June 2004, pp. 527-547. For an example of the application of this theoretical approach, see PS Juuti and TS Katko (eds.), From a few to all: long-term development of water and environmental services in Finland, (RT-Print OY, Pieksämäki, 2004).

113 See MC Lemos, J Recharte and C-T Chang, Integration of social science in the UNESCO's ecohydrology programme, (Report submitted by UNESCO's Ecohydrology Programme Special Science Task Force, Ann Arbor, 2007.04.18.

114 M Gibbons, C Limoges and H Nowotny (reds), The new production of knowledge: the dynamics of science and research in contemporary societies, (Sage Publications, Thousand Oaks, 1994). 
From the perspective of potential research funding and human resource management at universities and research institutions, the demand for greater transdisciplinary may well have a profound impact on monolithic scientific disciplines in future.

A field of investigation that deserves more attention from water historians is heritage and tourism studies. Clynnick's chapter on the Hartebeespoort irrigation scheme forms part of a study on the famous 'Cradle of Humankind' heritage site in South Africa's Gauteng Province. Other themes addressed in A search for origins: science, history and South Africa's 'Cradle of Humankind', include the history of science, palaeontology and the reappraisal of the heritage region a major tourism destination in the South African interior. ${ }^{115}$ In 2003 the Gauteng-based water utility, Rand Water, celebrated its centenary. Considerable attention was given to the history of potable water supply services to Gauteng and the neighbouring Mpumalanga, North West Province and parts of the Northern Free State. ${ }^{116}$ It became evident that using the water utility as a focal point it would be possible (for example in the Vaal Triangle, where much of Rand Water's water is processed) to develop opportunities to promote water heritage in a region that is bound to enter a phase of post-industrialisation in the future.

For some time to come the management history of South Africa's water resources and water catchments should be a priority in research. A recent publication by the department of water affairs and forestry (DWAF) provides an overview of South Africa's water supply and service delivery history in the period 1994-2004. Written from the perspective of aligning the country's water services sector with the more comprehensive millennium development goals (MDG), it provides information on some of the major accomplishments achieved in the new government's first decade. It also highlights the integrated legislation introduced and is generally informative on some of the problems experienced at governance level. ${ }^{117}$ The work can be of value for water historians as a platform to further research. However, one prerequisite would be to be access to primary source materials. The management of water for irrigation farming, which remains one of

115 See T Clynick, "White South Africa's weak sons: poor whites and the Hartebeespoort Dam" in P Bonner, A Esterhuysen and T Jenkins (eds.), A search for origins: science, history and South Africa's 'Cradle of Humankind', (Wits University Press, Johannesburg, 2007), pp. 248-273.

116 See Rand Water, 100 years of excellence 1903-2003, (Rand Water, Glenvista, 2004); M Bonner and P Lekgoathi, Rand Water 1903-2003, (Creda Communications, Johannesburg [?], 2004); JWN Tempelhoff, The substance of ubiquity: Rand Water 1903-2003, (Kleio, Vanderbijlpark, 2003).

117 RSA, Department of water affairs and forestry, A history of the first decade of water service delivery in South Africa 1994-2004, (Department of water affairs and forestry (DWAF), Pretoria n.d.). 
the major sectors of water consumption in South Africa, is important. More work, similar to the recent study by Beinart, for example, ${ }^{118}$ needs to be done.

Finally, South Africa's water history remains a project in the process of change and on-going development. It is evident that scholarship in the field can and should be expanded. In particular there is an urgent need for historians and natural scientists to work together. The work of McCarthy, Venter and Ellery on the Klip River is indicative of a valuable area for research collaboration between historians and natural scientists. ${ }^{119}$ Waterborne disease is currently responsible for the deaths annually of an estimated 1,6 billion children in all parts of the world. In South Africa there have been some serious outbreaks of typhus. Of particular significance were those in Delmas in the Mpumalanga Province in 2005; and there were indications of a new outbreak in 2007. The findings of recent health sciences research on the state of water-based disease in South Africa in 2000, offer a sound starting point for collaborative research by historians and their colleagues in the health sciences. ${ }^{120}$ Of particular importance here is the quantitative analysis and contemporary history of sewage pollution in South Africa's rivers by De Villiers and Thiart. ${ }^{121}$ What now remains to be done is for historians to fill in the detail with discourses human behaviour and interaction in the past. Work of this nature is of substantive importance for researchers interested in locating developmental trends in the country's water governance structures. This will inform our historical insight on the processes of institutional change over time. It would also be meaningful to look at strategies in transdisciplinary research methodologies that can integrate levels and forms of knowledge over a broad spectrum. ${ }^{122}$

$118 \mathrm{~W}$ Beinart, The rise of conservation in South Africa: settlers, livestock, and the environment 1770, (Oxford University Press, Oxford, 2003), pp. 158-194.

119 TS McCarthy, V Arnold, J Venter and WN Ellery, "The collapse of Johannesburg's Klip River wetland: research article" in South African Journal of Science, 103(9\&10), September-October 2007, pp. 391-397.

120 S Lewin, R Norman, E Thomas and D Bradshaw, "Estimating the burden of disease attributable to unsafe water and lack of sanitation and hygiene in South Africa in South African Medical Journal, 97(8) August 2007, pp. 755776.

121 S de Villiers and C Thiart, "The nutrient status of South African rivers: concentrations, trends and fluxes from the 1970s to 2005: research article" in South African Journal of Science, 103(7\&8) July-August, 2007, pp. 343-349.

122 In this respect, see for example strategies that have been introduced in Europe in C Pohl, G Hirsch Hadorn, Principles for designing transdisciplinary research: Proposed by the Swiss Academies of Arts and Sciences (Oekom Verlag, Munich, 2007) 